\title{
Negotiating Vulnerabilities in Space and Time in the Twenty-First Century
}

\author{
Rosalyn Black ${ }^{1}\left(\mathbb{D} \cdot\right.$ Lucas Walsh $^{2}$
}

Received: 12 August 2020 / Revised: 10 January 2021 / Accepted: 12 January 2021/ Published online: 18 February 2021

(C) The Author(s), under exclusive licence to Springer Nature Singapore Pte Ltd. part of Springer Nature 2021

\begin{abstract}
Young university students are experiencing a changing relationship with the future as economic and geopolitical anxieties alter the temporal and spatial horizons with which they engage. Du Bois-Reymond and López Blasco suggested almost 20 years ago that 'youth is now [...] a life condition that is marked by unpredictability, vulnerability and reversibility' (2003, p. 20). This situation has only accelerated since then. This paper draws on the authors' research in the UK, France and Australia to consider how university students imagine a future that is essentially unknowable. At the time of the authors' interviews, this future included conditions of vulnerability within the living social present that extended into the anticipated future and that ranged from the local to the global in their origins and impact. These conditions have since been even further exacerbated by the COVID-19 pandemic and the global recession accompanying it. Despite the uncertainty arising from these conditions of vulnerability, almost all interviewees read the future as possibility or potentiality as reported by Cook (Time \& Society 25(3): 700-717, 2016). The paper concludes that young people's lived experience of time and space is being reshaped by complex forces beyond their control as discussed by McLeod (British Journal of Sociology of Education 38(1): 13-25, 2017), but it also mounts an argument for the durability of young people's relationship to hope.
\end{abstract}

Keywords Higher education · University student · Vulnerability · Precarity · Hope

Submitted for inclusion in Youth, Education and the Ethos of Vulnerability in Uncertain Times: special edition of Journal of Applied Youth Studies

Rosalyn Black

rosalyn.black@deakin.edu.au

1 School of Education, Deakin University, Melbourne, Australia

2 Faculty of Education, Monash University, Melbourne, Australia 


\section{Introduction}

Change is always with us, but if one thing persists across fluid contemporary contexts, times and circumstances, it is the creation of 'truths of youth' (Kelly 2001) that foster specific constructions of groups of young people or of young people as a generational cohort. These truths promote various 'figures of youth' (Threadgold 2019), but there are a number of consistent themes. Some figures employ deficit stereotypes, signifiers or memes that establish young people as stigmas, scapegoats or folk devils (Threadgold 2019). Others promote youth as a category that is emblematic of a more hopeful future (Black 2018) or else that is subject to various vulnerabilities (Black and Walsh 2019; te Riele and Gorur 2015).

This last figure of youth has gained particular traction as a result of the uncertain circumstances that characterise the current era. Du Bois-Reymond and López Blasco suggested almost 20 years ago that 'youth is now [...] a life condition that is marked by unpredictability, vulnerability and reversibility' (2003, p. 20): this situation has only accelerated since then. Global labour markets have become more mutable; social fabrics have been strained by unprecedented human mobility and demographic change; deepening inequality has unsettled previously accepted ideas of social justice and cohesion; political orthodoxies have been upended; and planetary changes have called into question many other certainties of human life (Black and Walsh 2019). The COVID-19 pandemic and the global recession accompanying it have been identified as a potential opportunity for the development of a new social and political contract to counter some of these issues, but it has also exacerbated many of them in ways that are certain to have lasting effects on young lives. Our concern in this paper is primarily on the economic aspects and impacts of these developments.

A recent global survey suggests that over one in six young people have stopped working since the onset of the COVID-19 crisis (International Labour Organization 2020). While early analyses identify young people with lower levels of education as being amongst the most exposed to the increased job losses and decreased hiring rates that attend the pandemic (Cortes and Forsythe 2020), the university students who are our concern in this paper are also subject to these circumstances. The pandemic seems certain to see a further weakening of the bond between higher education and stable, secure professional employment. It is also associated with more immediate effects for higher education students. In Australia, for example, the casual employment on which an estimated $60 \%$ of full-time students rely has been severely disrupted. The sectors in which such students typically work have been most vulnerable to job losses, while those students who have been able to maintain employment during the pandemic have been at greater risk of catching the virus (Norton 2020). There are also signs that postgraduate students, some of whom are international students, are struggling with the economic fallout from the pandemic. One recent study suggests that $5 \%$ of current Australian PhD students are homeless or at risk of homelessness, that $11 \%$ are skipping meals and that 50\% are considering disengaging from their studies (Zhou 2020). Similar signals have been emerging from the United Kingdom (UK) (Smith 2020), where $30 \%$ of university students who responded to one particular survey had either lost their jobs or had their job offer cancelled or deferred because of the outbreak, and from France (Reuters 2020), where the financial impacts for some university students have been severe. 
Despite the compelling nature of these effects, we regard the pandemic as a context that at time of writing has emphasised trends that were already present for many young people in higher education. Its circumstances have exacerbated the challenges of an already intense competition for skilled labour, rising graduate unemployment and underemployment, and reduced graduate earnings premium or potential income power of graduates across numerous nations (Jackson 2020; Tomlinson and Nghia 2020). They have heightened existing conditions that render such young people vulnerable, constricting their mobility, eroding their economic security and intensifying the conditions of uncertainty that they must navigate. They have also seen a marked corresponding increase in the association between youth and vulnerability within the public domain. Media commentaries depict young people as members of 'Generation COVID' (Curnow and Knight 2020) who may face 'a lifetime (of) welfare dependency' (Stayner 2020a), a 'lockdown generation' (Crozet 2020) that is 'in danger of facing "devastating" long-term impacts' and subject to 'a "scarring effect" where a shadow is cast over future employment prospects' (Stayner 2020b). Young university students, more specifically, are described as members of a 'lost generation' (Reidy 2020) or of 'Generation Pandemic' who 'came of age at a time of fear and uncertainty' and whose lives and future trajectories are now variously depicted as 'interrupted', 'in limbo' and subject to a 'failure to launch' (Alter 2020).

\section{Revisiting Youth Vulnerability}

These media characterisations further amplify and add to the numerous policies, practices and interventions described by recent youth studies that construct young people as vulnerable (e.g. Brunila et al. 2019; Gallagher et al. 2017; Lessard et al. 2018; Noonan and Kelly 2020; Serrano Pascual and Martín Martín 2017; Sukarieh and Tannock 2016). As te Riele and Gorur observe, this vulnerability is sometimes depicted as the status or state of individual young people: at other times, it is constructed as a 'socio-political and historical production' that attempts to describe specific youth cohorts $(2015, \mathrm{p}$. 5). These depictions are often accompanied by institutional incitements and encouragements that attempt to foster young people's responses to their alleged vulnerability. What Padilla and Kelly have termed 'global grammars of enterprise' (Padilla and Kelly 2019, p. 63) are a common form of this. They encourage young people to develop such individualised skills and practices as adaptability, reflexivity and entrepreneurialism. As Colombo and Rebughini point out (Colombo and Rebughini 2019), they incite them to 'acknowledg[e] the necessity to work with and within the current situation, navigating among constraints' (p. 40) and 'to learn new languages, new codes and new rules to adapt to the different contexts in which they must act' (pp. 22-23). They also encourage young people to be constantly self-curating, committed to the "non-stop activity of investing in oneself' (Tejerina 2019, p. 96).

These practices are promoted not only as the basis for competitive advantage but as a necessary positioning of the self. The young person who adopts such practices embodies a specific selfhood, the selfhood of youth in conditions of vulnerability. This is, in varying forms, what has been described as the 'heroic figure' of the 'young entrepreneur' (Serrano Pascual and Martín Martín 2017), 'guerrilla selfhood' (Howie and Campbell 2016) and 'homo promptus' (Black and Walsh 2019). Young people 
who embrace such forms of selfhood are portrayed as having 'the brightest future potential' (Ikonen and Nikunen 2019, p. 825), a narrative that is applied with particular strength to university students.

In this paper, we consider recent portrayals of young university students as vulnerable subjects since the advent of COVID-19 but we also consider some of the narratives about such young people that were emerging before the pandemic. We draw on our 2018 interviews with university students in the UK, France and Australia to consider how such young people imagine a future that is essentially unknowable, a situation that has become the "new normality" of being adult today and in the foreseeable future' (Biasin et al. 2016, p. 37). We particularly reflect on the narratives of three of our interviewees: Becky in the UK, Zaynab in France and Alice in Australia. We suggest that their accounts bear out the observation that young people's lived experience of time and space is being reshaped by complex forces beyond their control (McLeod 2017), but we also mount an argument for the durability of young people's relationship to hope and the imagined future in ways that challenge constructions of 'vulnerable young people'. We conclude with some observations about ideas of vulnerability as they are commonly applied to young people. We suggest that the locus of vulnerability in contagious times is not young people themselves but the conditions which stretch or unravel the threads of hope that bind them to their imagined futures, especially in the context of university study which increasingly involves a gamble against unfavourable odds.

\section{The Study}

Our 2018 study interviewed 30 university students aged 18 to 30, all of whom were enrolled in public universities in Australia, France or the UK at the time. The study sought to understand the promises about young people's political, economic and social futures that are fostered by public universities in nations facing varying degrees of precarity. It also sought to investigate the hopes and plans held by young people at such universities for their own imagined futures and to identify the factors in the global socio-political climate that may support or undermine the realisation of those hopes and plans. Australia, France and the UK were selected because of their economic conditions and effects on young people's life outcomes at the time of the study. Each of these nations was selected as a point on a sliding scale of youth precarity: the UK occupied the most precarious end of the scale with high rates of youth unemployment, France in the middle was tipping towards poorer youth outcomes than in previous decades, and Australia occupied the least precarious end of the scale following two decades of strong economic growth.

Our total sample included 11 students from Australia, 11 from France and eight from the UK. Our sampling strategy was primarily a purposive one, although it was supplemented by convenience sampling to increase recruitment. Students in the UK and France were invited to participate via a snowballing technique facilitated by academics based at both universities. In Australia, the same technique was used alongside online advertisements for student networks. Sampling was not designed to control for variations such as gender, age, location or socioeconomic circumstances. Rather, it was designed to allow us to capture a series of individual accounts and to map some common themes in relation to the imagined futures described by a varied cohort of young people. 
Ethical approval for the study was attained from the respective universities in which the authors are based. Potential interviewees were invited to participate in individual semi-structured interviews of between 60 and 90 minutes in duration. The invitation to participate explained the primary aim of the study, which was to explore how young people understand and navigate uncertainty by investigating the experience of university students in Australia, France and the UK. It invited potential interviewees to consider and share their hopes, plans and concerns for their imagined futures, how these imagined futures related to their current experiences, and how their realisation may be supported or undermined by a range of economic and geopolitical circumstances.

A series of common questions, prompts and scenarios were used to ensure continuity within and across each series of semi-structured interviews while also allowing freeranging conversations within which interviewees could pursue their own lines of thought and discussion (Roulston and Choi 2018). The methodological intention underpinning these interviews was to encourage a series of point-in-time reflections that also encompassed the imagined future. All of these questions and prompts were future-focused and designed to generate 'future-oriented data' (Cuzzocrea and Mandich 2016): that is, they were all framed in a way that invited interviewees to share their imaginings of both their own personal futures and the collective or societal futures that may frame those personal futures. In order to give some shape and bring some continuity to these imaginings, all interview questions and prompts invited interviewees to describe how they imagined their lives in 10 years' time. In this way, the questions enabled us to follow the threads provided by interviewees from their current to their imagined future lives and selves.

With interviewees' prior permission, discussions were recorded, transcribed and thematically analysed (Miles et al. 2014). Interviewees also nominated whether to use their first names or pseudonyms. In each of the three national settings, the first two interviews were jointly conducted by the researchers to establish a common and stable approach: subsequent interviews in each nation were equally allocated between the researchers. The analysis of the data was undertaken in a similar manner. In the first instance, each interview transcript was analysed by each researcher, coding for linguistic or technical attributes and identifying overt semantic patterns such as keywords and repeated terms and phrases that can serve as 'condensation symbols for larger themes (Troyna 1994, p. 79). Broad codes and themes were agreed upon by both researchers. Initially, these were independently applied to the analysis of each interview and set of interviews by each researcher. These analyses were then jointly reviewed and refined.

As we have indicated above, an emphasis on future temporalities was central to our study and to our analysis of the data generated by it. Our interest in imagined youth futures took our lead from Leccardi's argument that 'youth, time and temporality are strictly intertwined' (in Leccardi et al. 2018, p. 10). We also responded to a growing youth scholarship which notes the challenges inherent in researching young people's relationship to the future and its nature as 'as a not-yet temporality' that is 'slippery, ill defined, constantly moving and, hence, intangible' (Coleman 2017, p. 525). Such arguments are only amplified by the challenges that arise from the pandemic: as we have previously noted, 'the association between young people and the future is a complex one, made more complex by uncertainty' (Black and Walsh 2019, p. 22). Our focus on youth temporalities in uncertain times sought, in McLeod's words, to 'surfac[e] time as an otherwise silent backdrop and organiser of structures and 
subjectivities' (McLeod 2017, p. 14). It also responded to a strong recent interest amongst youth scholars in the ways in which young people in variously precarious contexts imagine their educational and economic futures (e.g. Alexander et al. 2020; Cook 2018b; France et al. 2019; Nairn 2019; Ravn 2019).

Our study used the idea of imagined futures to invite nuanced discussions with our interviewees not only about the future imaginaries that motivate their hopes and plans but about 'the daily and wayfaring roots and routes of living' (Wood 2017, p. 10) that form essential past and present contexts for the formation of these imaginaries. This approach recognises that young people's imagined futures are deeply connected to present aspects of their lives such as their relationships with significant others; their past experiences and contexts; the resources which they have at their disposal; and the effects of current and possible future economic and geopolitical circumstances that now include a global pandemic. It recognises the contributions of scholars such as Cook (2018b) which show that young people's imagined futures respond and relate to forces beyond their own lives. It also recognises that young people's future imaginaries are inextricably bound up not only with their status or circumstances but with the person whom they may become: as Ravn points out, 'imagining futures also involves imagining futures selves' (Ravn 2019, p. 1041).

Following Cook (2018a), our study explored how our interviewees imagined and made sense of both their own personal or biographical future as well as the imagined collective or social future. While this paper focuses primarily on how they describe their personal imagined futures, their awareness of wider regional or global geopolitical phenomena also periodically emerges. We also explored the relationship for young people between the short-term and long-term imagined future, and the pressure and anxiety that arise as they attempt to plan for the future while being subject to constant short-termism in the form of labour market constraints. There were some boundaries to the temporalities we could address, however. Ours was not a longitudinal investigation, which means that we cannot make statements in this paper about how our interviewees' imagined futures have or may actually eventuate (Andersen et al. 2020). What we do instead is to consider the early evidence — and, indeed, the warnings - emerging from commentaries about the COVID-19 pandemic to locate our interviewees' narratives against the possible imagined futures that may face many recent and future graduates.

In this paper, we have selected three particular cases as the focus of our discussion, one from each of the three nations represented in the study. These three cases have been chosen because they exemplify key aspects of the themes that we identified within the wider data set. These themes were not limited to any one national sub-sample: rather, they emerged with surprising consistency across each of the three sub-samples. They took on particular strength within a number of specific cases, however. Each of our three cases in this paper was selected because it provides a strongly illustrative example of one of these key themes.

\section{Gambling with the Future: Becky in the UK}

Despite the conditions of vulnerability that we described earlier, higher education continues to transmit the promise of employment choice and security, earnings advantages, and resilience and agility in changing labour markets (Black and Walsh 2019). 
For most of our interviewees, this promise retained a great deal of power and appeal: higher education was both a safety net for the immediate future and an investment in their long-term security. This was certainly true for Becky in the UK, who was 25 at the time of our interview and an undergraduate student specialising in Forensic Psychology. She had returned to study after earlier attempts at other courses and after working in a range of areas, marrying and having a child. When we asked Becky what had motivated her to return to study, she laughed:

I was never much good with my hands. [...] my brain is my biggest asset. And it was stupid for me to think, oh, I will go and work in a shop - for me, it was like a waste. If you are good with your hands, you go and do something that's good with your hands. If you are an artist, you go and do art. I had a brain and I was like: well, this is my tool, I had better use it. It is the only thing I have bloody got, really.

For Becky, higher education was an essential aspect of her attempts and abilities to secure a desired and desirable future. It was intrinsic to her reading of the materialhistorical conditions of vulnerability in both her present and anticipated future. Her earlier comments capture her determination to make the best possible use of her personal capacities, but her deeper motivations for pursuing higher education had more to do with her anxieties about imagined economic uncertainty. These stemmed in large part from what she saw as a likely collective future, one that she feared may have a material impact on her own hopes: 'the next 30 years is really, really not good financially and everything else, because we are going to have no job prospects, no prospects of buying a home, no job security'. In pursuing higher education, she had also broken with the normative expectations that attend life in her rural village in southeast England. She described those expectations as they applied to her husband:

In that village, you were an anomaly if you went to university or even if you went to college. It was expected that you would get a trade: you would become a plumber, a builder, a carpenter, whatever. [...] You played rugby, you went out and got drunk every single weekend on a Friday night, you spent all of your wages that you had been making during the week, and that's what you did. And then, you got a girlfriend; you got married; you had kids; you settled down; you bought a house. That's your life.

In breaking with the past, Becky was attempting to weave a different future narrative for herself and her family. When we asked her to describe her life in 10 years' time, she described a life that stands in contrast with these expectations and with economic uncertainty, a life that is characterised by academic achievement and secure professional employment: 'I would have finished my Masters. I would hopefully be in a stable career in my chosen area. I quite like to maybe begin a $\mathrm{PhD}$ at that point'. She also described a life of economic stability for herself and her husband but most of all, 
for their young daughter: 'I'm going to buy a house so that I can give it to her, when I die, you know, so she's secure. That is the whole reason you want to do it'.

Becky believed that 'education is the gateway' to a more secure life, but she also acknowledged that it was in some ways a gamble, an investment in hope: 'it's like going into gaol on Monopoly, and then waiting the three goes to see if you roll a six'. Her hopes for the future were bound up in this gamble. They were also bound up in the imagined future self that might emerge from the gamble: 'In my future, I would like to become that person that people are going to call in, when they need someone that they know can do the job'.

\section{Vulnerability or Adaptability: Alice in Australia}

For Alice in Australia, too, higher education was a gateway or pathway to an imagined future security, but a much more ambiguous one. Alice was 28 years old and undertaking postgraduate studies when we met her. She had initially begun an Accounting degree, attributing her choice to her parents' encouragement:

They wanted me to do something professional, that I could get a real job. [...] I mean, being a tradie or something would not have been accepting because, you know, my sister and I are fairly academic and bright, so that would be seen as a bad option.

She discontinued this course to pursue a Music degree, but this did not lead to employment. Her parents were concerned ('well, you still don't have a real job and a real qualification'), so Alice agreed to embark on a Masters of Teaching specialising in Maths education. This was a purely pragmatic choice: 'I don't know if irony is the right word, but the fact is that I am already doing a degree that I don't really want to do, so let's do even more that I also don't want to do for a job that I don't want, to be an extra good Maths teacher'. She acknowledged that she had pursued this pragmatic pathway in response to her parents' concerns about the future: 'my parents are unbelievably influential and I listen to them way more than maybe I should, and I'm a good girl'. At the same time, she questioned the assumptions and promises on which this pursuit was based:

What does security mean? Does it even exist? I think there's this myth that certainly my parents buy into, that you can get this big, fat corporate job and climb the ladder and become a partner and get all these benefits, you know, they will look after you and all this. I don't think it is real. [...] I think people get made redundant whenever it suits the company. If they need to make more profits or 
whatever, they won't think twice: they'll just get rid of you. [...] I guess it's never been important to me, security.

She went on to explain:

I have always questioned the whole idea of the dream lifestyle, getting married, having a house and two cars and becoming a corporate lawyer or whatever and working 9 till 10, or whatever it is these days [...] until you die or you get old and then you retire and then your life can start. What the hell? Where does that make sense?

When we asked Alice what constituted a successful future, she replied: 'depending on who you are, the answer would be biased: like, depending on the people who I hang out, maybe for all my music, arty, alternative friends, maybe for all of us, we have different aspirations and success markers'. In fact, what emerges from her account is that she held very different ideas of success to her parents. Even though she had acceded to a normative set of future-focused assumptions and expectations and to a higher education pathway that may enable her to meet those expectations, meaningfulness and satisfaction still came from her music: 'I feel like my life matters when I am making art to music'. It is clear nonetheless that for Alice, as well as for her parents, music was not a viable economic choice. It was also affectively risky:

My parents don't value it: it kind of sets you up for a life of [...] constantly being the butt of family jokes and, like, the person that will possibly never own a house and the person that won't go on expensive holidays to Hawaii every year.

By contrast, undertaking a teaching qualification was an adaptive strategy: it is 'just do what you have to do to get by, I guess'. For Alice, the future was not woven in a predetermined way but constantly altered according to circumstances. This adaptive pragmatism came at a cost, however. Like her friends, Alice felt most herself when she was making music: 'the rest of the time, we are just kind of masquerading as, you know, happy, functional people'. Her teaching degree and the qualification and employment it promised were a necessary compromise, a safety net in the face of future uncertainty, but also a choice that sacrificed the present to the possible future, as Alice explained:

So it's kind of a sacrifice but at the same time it is also the best gift that you can give to yourself. I think I am really good at forcing myself to do stuff that I don't want to do and that I, like, a die a bit inside. 


\section{Imagining the Mobile Future: Zaynab in France}

Despite their anxieties about uncertainty and the adaptive choices which many had made to obviate that uncertainty, most of our interviewees read the imagined future as possibility or potentiality (Cook 2016), one characterised by experimentation, enjoyment, and desired and elective mobilities. Zaynab in France was 23 at the time of our interview and undertaking a Master of International Journalism. Like Alice, she had chosen a higher education pathway in part because of family norms and expectations: 'education was always important in my family. I was always encouraged to pursue higher education; a minimum, at least, an undergraduate degree'. She also articulated the hopes invested in her higher education in ways that her family would support and understand: when we asked her to imagine her working life 10 years from the time of our interview, Zaynab described her desire to feel 'financially secure, in whatever job I have'.

At the same time, like Alice, she challenged the idea that higher education could still be a pathway to such security: 'I don't think stable and secure is common anymore or realistic anymore'. Instead, Zaynab placed considerable value on the notion of flexibility and mobility. Describing her initial higher education choices, she explained:

I wasn't too sure about what I was going to do. I considered going into teaching, but I figured that I could always go back to teaching, after having a career somewhere else. So I didn't know if I wanted to start with that right away.

These ideas and values also informed her imaginings of her life in 10 years time. This imagined future was above all a mobile one, one in which Zaynab would have the ability to choose where she worked and lived: 'that would be my vision of success at that point'. It was also one in which Zaynab could travel freely: 'I could probably see myself being in a more flexible position where I could travel a lot and not be attached to one place'. Her vision of how she might utilise her qualification was equally fluid: 'down the line it could be teaching, teaching foreign languages; but it could be working in the private sector, companies, international, multi-national companies, things like that, that would allow that flexibility'. This flexibility was more important to Zaynab than the achievement of normative markers of adulthood and success such as home purchase: 'I would see myself not buying a house in ten years, for example, and moving around'. It was also, potentially, more important than forming a romantic partnership or a family:

I don't think I have that priority of finding a partner and having a family. I have been so, sort of, interested in languages for so long: I just want to make sure I have a job that can sort of fit that passion, those requirements. So I would say I would be fine single, I think.

When we asked her to consider the markers of adulthood for contemporary young people and how they compared to the experience of her parents, change, fluidity and flexibility emerged as guiding themes once more: 
I mean, we are growing in a totally different world. I don't think it's fair to say [...] that it's hard to get a secure job as you don't have as many responsibilities as young [people] before, in another age for another generation. But another argument is: it's more difficult to do everything, so you have no other choice but to sort of handle everything on your own quicker.

For Zaynab, adulthood and the imagined future was very much about the individualised curation of one's own life success: 'I think an adult is someone who is independent enough to make their own decisions on how to shape their own lives, to the best of their ability, and someone who tries to improve their own life, whether it be through studies or through work progression'. At the same time, she had no illusions that the future would be subject or obedient to individualised attempts at control or curation. Like our other interviewees, she was 'always sort of ready for the worst', as she explained:

That's my mum's philosophy, too, so I take that from her. So yeah, I think it's those - maybe a form of protection as well. If things don't work out anyways, you didn't expect it to happen, so that's fine (laughs).

Zaynab's imagined future was therefore not entirely individualised, but was threaded back to her family experiences. Her relationship to that imagined future was also informed by the importance of 'self-preservation', of balancing hopes with a pragmatic recognition of the uncertainties that may interfere or intervene in the realisation of those hopes.

\section{Conclusion}

As we have previously argued, 'young lives - idealised and otherwise - resist neat categorisation' (Black and Walsh 2019, p. 2). The young people whose accounts we consider in this paper did not necessarily occupy the kinds of youth categories that are commonly constructed as vulnerable, but they were certainly subject to conditions of vulnerability within their living social presents that extended into their anticipated or imagined futures. These included local circumstances such as the uncertainty of graduate employment as well as the wider geopolitical forces that contribute to that uncertainty. All were keenly aware of these conditions and circumstances and of the impact that these were likely to have on their imagined and desired futures. All employed strategies to 'manage' uncertainty, bolstered by hope. Their responses and strategies remained complex, however.

For Alice, the decision to gamble on a Music degree gave way to the pragmatic (if somewhat pressured) choice to study Maths education. In one sense, Alice is attempting to mitigate that possibility of insecure work by investing in a teaching degree. In Becky's case, hope is an investment, a form of future-oriented resource that is coupled to her investment in something that very well may not pay off for her in the long run. Cognisant of this, Becky pushes on in ways that reflect the vulnerability of young people to uncertainty and the insecurity that attends it. For Zaynab, the future offers hopeful prospects, but hope is balanced and mitigated by the risk that these 
prospects may not be realised. Like Alice and Becky, Zaynab openly acknowledges this risk: her response is to do what she can to shape her life and to adapt to circumstances as they arise.

Nearly all of our interviewees expressed their hopes that the future would bring them labour market security in their chosen fields: at the same time, they voiced a belief that the workforce of the future would be highly competitive. Most were optimistic about their imagined working futures, but nearly all acknowledged the spectre of uncertainty that attended those futures and the need to make pragmatic and adaptive choices in response. All had made a considered decision to pursue a higher education qualification which they regarded as a key to their imagined futures, but not all expressed faith or trust in the realisation of the promises inherent in that qualification.

The emerging effects of the pandemic make it likely that more young people currently or recently in higher education will be subject to these conditions of vulnerability, which are complex and nuanced. As firms and public sector agencies reduce their graduate recruitment, as wages freeze and as established graduate pathways to employment such as internships and work placements evaporate, many are likely to find themselves needing to rethink or reorient their plans in search of employability, while poor labour market entry prospects may encourage others to accept lower-paid positions which may have ongoing effects on their careers (Amin 2020; d'Orville 2020).

Other experiences in which the imagined futures of many are invested will also be inevitably deferred or curtailed. We noted in 2019 that 'higher education is imbued with the discursive promise that graduates will be able to take their place as mobile global (and globalised) citizens with broad career prospects and capacities to contribute politically, economically and socially across national and world stages' (Black and Walsh 2019, p. 6). These mobilities and the benefits implicit in them are rapidly becoming more difficult to access as the pandemic fuels a growing backlash against the principles and practices of globalisation as the basis for economic and other relationships between nations: not only the practicalities but the philosophy of open borders and markets is under increasing global scrutiny and challenge (Goodman 2020).

The conditions of vulnerability are undoubtedly escalating for our interviewees, but it is not our intention to depict them as vulnerable. In considering their research with young Aboriginal people in Canadian schools, Lessard, Caine and Clandinin ask: 'Who gets to name vulnerability? What is vulnerability?' (2018, p. 191). What they call the 'assigned vulnerabilities' (p. 203) that are applied to young people as a generational cohort and, increasingly, to young university students and graduates conceal and overlook the durability of young people's relationship to hope. They also serve to deflect attention from the structural nature of the conditions of vulnerability to which young people are subject, rendering young people individually responsible for their own present and future circumstances and placing the onus on them to generate resilient and enterprising responses.

What is vulnerable here are the frayed threads that bind this education to young people's imagined futures. The material conditions unfolding during COVID-19 reflect deeper, persistent distresses to that fabric. The promises of higher education as a means to economic security and global citizenship are rendered more faded and wrinkled, if not shredded by unfolding economic, social and political upheavals throughout the world. As the effects of the global pandemic continue to unfurl, the present of young people is one in which they find themselves physically locked in tight, narrow 
geographies that must be negotiated incrementally on a day-by-basis. Such conditions were previously evident, but have been rendered visible, urgent and seemingly inescapable. To invest in university study increasingly necessitates gambling against unfavourable odds that are stacked against young people whose present and future lives are currently in lockdown.

Code availability Not applicable.

Data Availability Not applicable.

\section{Declarations}

Ethical approval All procedures performed in studies involving human participants were in accordance with the ethical standards of the institutional and/or national research committee and with the 1964 Helsinki declaration and its later amendments or comparable ethical standards.

Informed consent Informed consent was obtained from all individual participants included in the study.

Conflict of interest The authors declare no conflict of interest.

\section{References}

Alexander P, Loewenthal J, Butt G (2020) 'Fuck It, Shit Happens (FISH)': a social generations approach to understanding young people's imaginings of life after school in 2016-2017. Journal of Youth Studies 23(1):109-126. https://doi.org/10.1080/13676261.2019.1704406

Alter, C (2020) How COVID-19 will shape the class of 2020 for the rest of their lives. Time. https:/time.com/ 5839765/college-graduation-2020/. Accessed 21 May 2020

Amin, M (2020) Coronavirus pushes millennials to re-skill or face years of wage inequality. ABC News. https:/www.abc.net.au/news/2020-06-06/coronavirus-will-leave-biggest-scar- on-new-graduates/ 12324244. Accessed 21 June 2020

Andersen D, Ravn S, Thomson R (2020) Narrative sense-making and prospective social action: methodological challenges and new directions. International Journal of Social Research Methodology 23(4):367-375. https://doi.org/10.1080/13645579.2020.1723204

Biasin C, Cornacchia M, Marescotti E (2016) Expectations and young hopes: a research with graduate students in Education. Studi sulla Formazione/Open J Educ 2:37-57. https://doi.org/10.13128/Studi Formaz-20202 Author details removedAuthor details removed

Black R (2018) Making the hopeful citizen in precarious times. In: Campbell P, Harrison L, Hickey C, Kelly $\mathrm{P}$ (eds) Young people and the politics of outrage and hope. Brill, Amsterdam, pp 128-139

Black R, Walsh L (2019) Imagining youth futures: university students in post-truth times. Springer, Singapore

Brunila K, Mertanen K, Tiainen K, Kurki T, Masoud A, Mäkelä K, Ikävalko E (2019) Vulnerabilizing young people: interrupting the ethos of vulnerability, the neoliberal rationality, and the precision education governance. Journal of the Finnish Anthropological Society 43(3):113-120. https://doi.org/10.30676/jfas. v43i3.82737

Coleman, R (2017) A sensory sociology of the future: affect, hope and inventive methodologies. The Sociol Rev 65(3): 525-543. https://doi.org/10.1111/1467-954X.12445

Colombo, E, Rebughini, P (2019) A complex uncertainty: Young people in the riddle of the present. In E Colombo and P Rebughini (Eds.) Youth and the politics of the present: coping with complexity and ambivalence. Routledge, London \& New York, pp 1-16

Cook, J (2016). Young people's strategies for coping with parallel imaginings of the future. Time \& Society 25(3): 700-717. https://doi.org/10.1177/0961463X15609829

Cook J (2018a) Gendered expectations of the biographical and social future: Young adults' approaches to short and long-term thinking. Journal of Youth Studies 21(10):1376-1391. https://doi.org/10.1080/ 13676261.2018.1468875 
Cook J (2018b) Imagined futures: hope, risk and uncertainty. Cham, Switzerland, Springer

Cortes, GM, Forsythe, EC (2020) The heterogeneous labor market impacts of the Covid-19 pandemic. Upjohn Research, Upjohn Institute working paper 20-327. 10.17848/wp20-327

Crozet, M (2020) 'Lockdown generation' of young workers will need extra help after COVID-19, urges UN labour chief. UN News. https://news.un.org/en/story/2020/05/1064912. Accessed 27 May 2020

Curnow, S, Knight, B (2020) Generation COVID. ABC Investigations and ABC Victoria. https://www.abc. net.au/news/2020-07-06/generation-covid-faces-an-uncertain- future/12388308?nw=0. Accessed 20 July 2020

Cuzzocrea V, Mandich G (2016) Students' narratives of the future: Imagined mobilities as forms of youth agency? Journal of Youth Studies 19(4):552-567. https://doi.org/10.1080/13676261.2015.1098773

d'Orville, H (2020) COVID-19 causes unprecedented educational disruption: is there a road towards a new normal? Prospects 1-5. doi:10.1007/s11125-020-09475-0

Du Bois-Reymond M, López Blasco A (2003) Yo-yo transitions and misleading trajectories: towards integrated transition policies for young adults in Europe. In: López Blasco A, McNeish W, Walther A (eds) Young people and contradictions of inclusion. The Policy Press, Towards integrated transition policies in Europe. Bristol, pp 19-41

France A, Pukepuke T, Cowie L, Mayeda D, Chetty M (2019) 'Imagined futures' in the navigation and management of uncertainty for young women in Aotearoa, New Zealand. Journal of Sociology 55(4): 654-669. https://doi.org/10.1177/1440783319888281

Gallagher, K, Starkman, R, Rhoades, R (2017) Performing counter-narratives and mining creative resilience: using applied theatre to theorize notions of youth resilience. J Youth Studies 20(2): 216-233. doi:https:// doi.org/10.1080/13676261.2016.1206864

Goodman, PS (2020) A global outbreak is fueling the backlash to globalization. New York Times. https:// www.nytimes.com/2020/03/05/business/coronavirus-globalism.html. Accessed 16 June 2020

Howie L, Campbell P (2016) Guerrilla selfhood: imagining young people's entrepreneurial futures. Journal of Youth Studies 19(7):906-920. https://doi.org/10.1080/13676261.2015.1123236

Ikonen, HM, Nikunen, M (2019) Young adults and the tuning of the entrepreneurial mindset in neoliberal capitalism. Journal of Youth Studies 22(6): 824-838. https://doi.org/10.1080/13676261.2018.1546383

International Labour Organization (2020) ILO Monitor: COVID-19 and the world of work. www.ilo.org. accessed 16 June 2020

Jackson, D (2020) The changing nature of graduate roles and the value of the degree. J Higher Educ Policy Manag 1-16. doi:https://doi.org/10.1080/1360080X.2020.1777634

Kelly P (2001) Youth at risk: Processes of individualisation and responsibilisation in the risk society. Discourse: Studies in the Cultural Politics of Education 22(1):23-33. https://doi.org/10.1080/ 01596300120039731

Leccardi, C, Cuzzocrea, V, Bello, BG (2018) Youth as a metaphor: an interview with Carmen Leccardi. J Modern Italian Stud 23(1): 8-23. https://doi.org/10.1080/1354571X.2017.1409522

Lessard S, Caine V, Clandinin DJ (2018) Exploring neglected narratives: understanding vulnerability in narrative inquiry. Irish Educational Studies 37(2):191-204. https://doi.org/10.1080/03323315.2018. 1465835

McLeod, J (2017) Marking time, making methods: Temporality and untimely dilemmas in the sociology of youth and educational change. British J Sociol Educ 38(1): 13-25. https://doi.org/10.1080/01425692. 2016.1254541

Miles, MB, Huberman, AM, Saldaña, J (2014) Qualitative data analysis: a methods sourcebook. Sage, Thousand Oaks

Nairn K (2019) Learning from young people engaged in climate activism: the potential of collectivizing despair and hope. Young 27(5):435-450. https://doi.org/10.1177/1103308818817603

Noonan, M, Kelly, P (2020) Young people and the gendered and aesthetic dimensions of 'enterprise': stories from a 'Rust Belt' city. Journal of Youth Studies 23(4): 481-498. https://doi.org/10.1080/13676261.2019. 1620927

Norton, A (2020). The student workforce and COVID-19. https://andrewnorton.net.au/2020/03/16/thestudent-workforce-and-covid-19/. Accessed 13 June 2020

Padilla, DC, Kelly, P (2019) Young people, precarity and global grammars of enterprise: some preliminary provocations. RECERCA. Revista de Pensament y Anàlisi 24(1): 61-91. https://doi.org/10.6035/Recerca. 2019.24.1.4

Ravn S (2019) Imagining futures, imagining selves: a narrative approach to 'risk' in young men's lives. Current Sociology 67(7):1039-1055. https://doi.org/10.1177/0011392119857453 
Reidy, T (2020) 'Recruitment is on hold': the students graduating into the Covid-19 recession. The Guardian. https://www.theguardian.com/education/2020/apr/10/recruitment-is-on- hold-the-students-graduatinginto-the-covid-19-recession. Accessed 10 April 2020

Reuters (2020) Confined by lockdown, some students in France queue for donated food.

Roulston, K, Choi, M (2018). Qualitative interviews. In U Flick (Ed.) The SAGE handbook of qualitative data collection. SAGE, London, pp 233-249

Serrano Pascual A, Martín Martín P (2017) From 'Employab-ility' to 'Entrepreneurial-ity' in Spain: youth in the spotlight in times of crisis. J Youth Stud 20(7):798-821. https://doi.org/10.1080/13676261.2016. 1273513

Smith, MS (2020) Survey reveals students' concerns amid coronavirus crisis. https://luminate.prospects.ac.uk/ survey-reveals-students-concerns-amid-coronavirus- crisis. Accessed 10 November 2020

Stayner, T (2020a) As unemployment spikes, the dire job market for young Australians is 'imploding'. SBS News. https://www.sbs.com.au/news/as-unemployment-spikes-the- dire-job-market-for-youngaustralians-is-imploding. Accessed 18 June 2020

Stayner, T (2020b) Young Australians forced out of work by coronavirus face 'devastating' long- term impacts. SBS News. https://www.sbs.com.au/news/young-australians-forced-out- of-work-bycoronavirus-face-devastating-long-term-impacts. Accessed 26 May 2020

Sukarieh M, Tannock S (2016) On the political economy of youth: a comment. J Youth Stud 19(9):12811289. https://doi.org/10.1080/13676261.2016.1206869

te Riele K, Gorur R (2015) Vulnerability: construct, complexity and consequences. In: Te Riele K, Gorur R (eds) Interrogating conceptions of "vulnerable youth" in theory, policy and practice. Sense Publishers, Rottterdam, pp 3-16

Tejerina, B (2019) Youth and precariousness in Spain: beyond a waiting time. In E Colombo and P Rebughini (Eds.), Youth and the politics of the present: coping with complexity and ambivalence). Routledge, London \& New York, pp 88-100

Threadgold, S (2019) Figures of youth: on the very object of Youth Studies. J Youth Stud 1-16. https://doi.org/ $10.1080 / 13676261.2019 .1636014$

Tomlinson M, Nghia TLH (2020) An overview of the current policy and conceptual landscape of graduate employability. In: Nghia TLH, Pham T, Tomlinson M, Medica K, Thompson CD (eds) Developing and utilizing employability capitals: Graduates' strategies across labour markets. Routledge, Oxon

Troyna, B (1994) Critical social research and educational policy. British J Educ Stud 42(1): 70-84. https://doi. org/10.1080/00071005.1994.9973984 author details removed

Wood, BE (2017) Youth studies, citizenship and transitions: towards a new research agenda. J Youth Stud 20 (9): 1176-1190. https://doi.org/10.1080/13676261.2017.1316363

Zhou, N (2020) Almost half of Australian PhD students considering disengaging from studies due t pandemic. The Guardian https://www.theguardian.com/australia- news/2020/jul/10/almost-half-of-australian-phdstudents-considering-disengaging- from-studies-due-to-pandemic?CMP=Share_iOSApp_Other. Accessed 10 July 2020 